\title{
Politics of Identity and Counter-Hegemony: Lopes-Graça and the Concept of "National Music"
}

\section{MÁRIO VIEIRA de CARVALHO}

The idea of "national music" plays a paramount role in the theory and praxis of the Portuguese composer Fernando Lopes-Graça (1906-1994), who was confronted with it in the 1920s, when 'nationalism' increasingly influenced different ideological discourses and became entangled in arts and music. In this paper, I begin with a brief historical retrospective in order to situate the "position" of LopesGraça and discuss the circumstances in which he first joined the mainstream, then radically broke with it, and finally developed what I call a counter-hegemonic "politics of identity," based on a particular concept of "national music": a concept not yet given, but still to be constructed. Lopes-Graça was able to inscribe this concept within a broader strategy of cultural resistance against the Estado Novo (the "New State"), including alternative, counter-hegemonic structures of communication.

\section{The sentiment of decadence and nationalism}

In Portugal, the turn to "musical nationalism" dates back to the end of the 19th century, with the pianist and composer José Viana da Mota (1868-1948) and the composer Alfredo Keil (1850-1907). ${ }^{2}$ It coincides, on the one hand, with a prevailing sense that Portugal had lapsed into decadence, aroused by the colonial crisis and the British ultimatum (1890) concerning certain Portuguese territorial ambitions in Africa, and, on the other hand, with the rise of the Republican movement, which had grown in influence since 1880 as a "patriotic" alternative to the establishment. The fanfare of the last section-Ressurgimento ('Resurgence')—of the Symphony "à Pátria" (dedicated to the homeland), written by Viana da Mota in 1895 (immediately after his entry into Freemasonry), seems to anticipate the Republican victory of 1910. Keil's A Portuguesa — a patriotic song in the spirit of the Marseillaise composed in 1890 in response to the British ultimatum — would be adopted in 1911 as the Portuguese national anthem (it remains so today).

After the proclamation of the Republic in 1910, however, the trend towards greater democracy persisted, and, at the same time, nationalist tendencies gained more and more influence. The laicization of the State and the huge educational program established by the new Republican power threatened centuryold privileges of the Church and clergy, while the absence of structural reforms and the political instability of the regime created the conditions for the emergence of a dictatorial principle. The context was favorable to the influence of the ideas of the Action Française and Charles Maurras, which would be embraced by a political bloc, the so-called "Integralismo Lusitano," bringing together Catholics, Monarchists, and dissidents of the Republican parties. ${ }^{3}$

\footnotetext{
${ }^{1}$ On a "politics of identity" as a "politics of position," see Stuart Hall, “Cultural Identity and Diaspora," in Identity: Community, Culture and Difference, ed. Jonathan Rutherford (London: Lawrence \& Wishart, 1990), 226.

2 “"Considerably later than in other countries' -." See Ferreira de Castro's critical overview of the emergence of “"musical nationalism"” in Portugal: P. Ferreira de Castro, "Musical Nationalism, or the Ambiguities of Portugueseness," in Portugal and the World - The Encounter of Cultures in Music, ed. Salwa El Shawan Castelo-Branco (Lisbon: Publicações Dom Quixote, 1997), 163-70.

3 "Lusitânia" was a province of the Roman Empire, partially comprising of the future territory of Portugal. The "Lusitanos," inhabitants of this territory, are considered the oldest ancestors of Portuguese people. The denomination "Integralismo
} 
The first Republican dictatorship, inaugurated in 1917 (the same year as the "miracle" of Fátima) and led by President Sidónio Pais, and Pais's murder one year later, are at the same time a consequence and a factor in a radicalization of positions. The fact that Sidónio Pais's photo became an object of cult worship alongside the "Blessed Virgin of Fátima," especially in rural areas, is one of many signs of the active involvement of the clergy in the political struggle, and helps us to understand the conservative ideological melting-pot in which politics, religion, and aesthetics (music included) mixed, giving rise to very different connections within the broader discourse of nationalism.

So, in the musical field, nationalism was claimed in the 1920s, for instance, by Rui Coelho (18891986). His patriotic Camoens-Symphonies (1913 and 1917), the Fátima-Oratorio (1931) celebrating the "miracle" of the Virgin in 1917, the Canções de Saudade e Amor ("Songs of Nostalgia and Love") (1917)_ both of the latter based on texts by the nationalist poet Afonso Lopes Vieira-as well as his symphonic poems, operas, and Portuguese Suites represented the populist trend within nationalism. Catholicism, the ideology of saudosismo (nostalgia) and the search for a dictatorial leader ("nostalgia for the leader we need," in the words of his friend António Ferro, the future Secretary for Propaganda under Salazar's regime) inspired these works. ${ }^{4}$ Musically, Coelho followed the dominant view of what "Portuguese" music should be: rooted in fado, the so-called "national song," certain "popular" melodies or dances, traditionally reproduced or re-invented for theatre or, later, from the 1930s, for broadcast and films such as $A$ Severa (1931), the story of a legendary female fado singer. ${ }^{5}$

Another nationalist trend, this time closer to the Catholics of the "Integralismo Lusitano," was originated by the group "Renascimento Musical" ("Musical Renaissance"), the aim of which was to discover early Portuguese music, namely Church music from the Renaissance to the 18th century. Its political ideal was to bring the country back to its "ancient greatness and virtues," foregoing liberalism and a constitutional monarchy. Accordingly, this group condemned the laicization of musical education that liberalism had started in Portugal in 1835, and, in its most radical manifestation-expressed in 1926 by the journal Ordem Nova, an organ of the Catholic rationalists, or neotomists_rejected the whole of music from the Renaissance onwards as a "universe glowing with sin." Nevertheless, some composers of this group also attempted to create a kind of national music inspired by popular sources: this was the case with Ivo Cruz (1901-1985) in his mythical evocations of the early origins of Portugal (Nocturnos da Lusitânia), or Mário Sampaio Ribeiro in his song arrangements as a choral inspector of the "Mocidade Portuguesa."

When the military putsch of 28 May 1926 took place, paving the way for the "New State" (a Fascisttype dictatorship), Fernando Lopes-Graça was still a nineteen-year-old student at the Conservatory of Lisbon. In his first work, Variações sobre um tema popular português ("Variations on a Portuguese Folk Theme”), for piano (1927), Lopes-Graça joined the musical mainstream. In 1927 he did not establish any fundamental difference between his approach in attempting to compose a "national" piece of music and

\footnotetext{
Lusitano" brings together the Portuguese translation of intégrisme (French) (the term “integrismo” exists also in Portuguese) and the idea of a "racial" origin.

${ }^{4}$ For further details, see Mário Vieira de Carvalho, 'Pensar é morrer', ou O Teatro de São Carlos na mudança de sistemas sociocomunicativos (Lisbon: Imprensa Nacional - Casa da Moeda, 1993), 176-93; or 'Denken ist Sterben.' Sozialgeschichte des Opernhauses Lissabon (Kassel: Bärenreiter, 1999), 221-44.

${ }^{5}$ A film directed by Leitão de Barros with music by Frederico de Freitas (1902-1980).

${ }^{6}$ Vieira de Carvalho, 'Pensar é morrer,' 192; or 'Denken ist Sterben,' 242.

${ }^{7}$ The "Portuguese Youth," created in 1936, was the equivalent of the Hitler Youth. On its choral repertoire, based on folk sources, and its nationalist goals, see the detailed analysis in Manuel Deniz Silva, "Usos e abusos do folclore musical pela Mocidade Portuguesa," in Vozes do Povo - A Folclorização em Portugal, ed. Salwa Castelo-Branco and Jorge Freitas Branco (Oeiras: Celta Editora, 2003).
} 
that of Rui Coelho. Lopes-Graça had enthusiastically applauded the first performance of the nationalist Opera Inez de Castro by Coelho, which was staged in $1926 .{ }^{8}$

Furthermore, his first piano piece reflected the tendency that was also dominant at the Conservatory of Lisbon, originating from Viana da Mota's early tradition of musical nationalism, and advocated by the latter in his inaugural speech as Director (1919). ${ }^{9}$ Other members of the teaching staff repeated the same call to the young composers to work on the "traditional melodies of the peasants" not "made familiar in our more civilized centres,"

\section{Lopes-Graça's break with nationalism}

Although Lopes-Graça's first piano piece, in which traits of his later approach to folk sources are recognizable, already reveals his personal style, it must be reconsidered in a new light: no longer as the beginning of his own aesthetic project, but as the end of his academic training as a composer. In fact, Lopes-Graça's break with any kind of "national music" took place shortly after, in the same year (1928) as his first public performance as a pianist and a composer; not by chance, this was also the year in which he began to be openly engaged in political struggle.

In fact, in 1928 he founded and ran an opposition newspaper in his hometown. Titled $A$ Aç̧ão, it promoted republican, anti-clerical, socialist, and even communist ideas. It is, therefore, no wonder that he began to regard the nationalist ideology and the ideal of a national music with suspicion. In his newspaper, the Russian Revolution, characterized as "redeeming the revolution of labour," was placed in opposition to Maurras' "integralism," ${ }^{2}$ and all forms of nationalism were discredited, including explicitly those concerning music: the "Renascimento Musical," 13 or the national schools of other countries, including Manuel de Falla's music, which was deprecated as nacionalismo castanholeiro ("a nationalism of castanets"). ${ }^{14}$

Against the mainstream, and consistent with the views of ethnologist Armando Leça, ${ }^{15}$ Lopes-Graça's newspaper repudiated the status of fado as "the national song par excellence" and denied that it belonged to "folk music." Fado was here characterized as "the principal sign of our mental inferiority, of our intellectual and artistic apathy," as a sign of "moral baseness, morbid sentimentalism, lack of aesthetic culture not only of the bas-fond, the rabble, but also of many people of good breeding." "Mass-produced by the writers of revues"-according to the same article, surely written by Lopes-Graça-fado represented for the author only the lumpen idiosyncrasy, shared by "debauched noblemen of the past century" and which "nowadays has become fashion in the salons of high society."

After his imprisonment as a member of the Communist Organization of Tomar and the closing of his newspaper by the police, Lopes-Graça published a fierce review of the film A Severa in another leftwing

\footnotetext{
${ }^{8}$ Lopes-Graça, “As óperas de Rui Coelho e o problema da ópera portuguesa,” in Obras Literárias (Lisbon: Caminho, 1989), $6: 166$.

${ }^{9}$ See Viana da Mota interviewed by Lopes-Graça in the left periodical O Diabo, June 26, 1940, quoted in Lopes-Graça, "Sobre o conceito de música portuguesa," in Obras Literárias (Caminho), 6:54.

${ }^{10}$ Eugénio Vieira, A Música, December 15, 1918.

${ }^{11}$ Alexandre Rey Colaço, De Música (Lisbon: Imprensa Libanio da Silva Rey Colaço, 1923).

${ }^{12}$ Lopes-Graça, $A$ Acção, December 30, 1928.

${ }^{13}$ Ibid., January 6, 1929.

${ }^{14}$ Ibid., January 19, 1930.

${ }^{15}$ In his book Da música portuguesa (On Portuguese music), Leça argued for systematic research into rural music and categorically rejected fado as "national song" (Lisbon: Lúmen, Empreza Internacional Editora, 1922).

${ }^{16}$ A Acção, May 19, 1929.
} 
periodical, Seara Nova (July 23, 1931). In the review he described, in a most eloquent manner, the extent of his rejection of a given Portuguese "national identity":

Definitively: I am denatured, a déraciné...Although born and brought up in Portugal, I feel more and more my incapacity to feel and understand Portuguese things; and thus I consider myself as one of the greatest exceptions to that brilliant ethno-psychological law, which was formulated by a known Portuguese journalist: that being born in Portugal is absolutely necessary to feel and understand our things...I impute this deficiency of my spirit to my lack of three main racial virtues: to write verses, to like bullfighting and to love $f a d o .{ }^{17}$

A more categorical and radical affirmation of Lopes-Graça's Otherness towards the given, hegemonic national identity would be hard to find. ${ }^{18}$ In fact, at this time, as is evidenced by his correspondence, Lopes-Graça had a very skeptical attitude towards any kind of "nationalism" in art, including the output of Luís de Freitas Branco (1890-1955)—a composer particularly respected by him—who had just composed two Suites Alentejanas for orchestra. They meant, according to Lopes-Graça, "to defeat Ruy Coelho on his own ground"-which demonstrates very clearly that Lopes-Graça was not at all concerned about such a "ground" at that time. It had nothing to do with his ideas as a composer.

In another text from 1931, Lopes-Graça emphasizes the universalism of Portuguese civilization and culture by taking a position against the belief in "autochthonous cultures, stemming from a race [born] like Minerva from Jupiter's head.” Portuguese civilization, he argues, had culminated in the 16th century, after which intellectual, artistic, and musical decadence set in as a consequence of the isolationism imposed by the Church and the Inquisition. ${ }^{19}$

Accordingly, he stresses the lack of continuity of Portuguese music, the lack of a dynamic tradition based on the dialectics between the local and the universal. ${ }^{20}$ By referring to Viana da Mota's and Keil's attempts to create a national music against Italianism and by denouncing the confusion between national art and nationalism as ideology, Lopes-Graça once again distances himself from national music projects based on folk sources. This confusion of "musical" and "political" nationalism is the main reason that Lopes-Graça later invokes again to justify his "scepticism" concerning "national music." 21

Lopes-Graça thus follows the same argument that had been advanced earlier by the group of left intellectuals of the periodical Seara Nova, founded in 1921, which defined itself as "a strenuous adversary of the nationalist ideal ... as well as of the confusions and equivocations caused by the illegitimate transference of so-called 'nationalism' in the field of art, literature and history to the social and political field." 22 But, behind this rejection of the transference of "nationalism" from politics into art obviously lay a political position as well, which, in the case of Lopes-Graça, was very clearly signaled by his involvement in the Communist Organization of Tomar and campaign for internationalist ideals in the newspaper $A$ Acção.

Moreover, Lopes-Graça's break with the given and hegemonic "national identity"-this moment of desidentification that characterizes his musical work and persisted for almost ten years-corresponds exactly to the period involving the gradual organization of folklore as propaganda by the "New State." This

\footnotetext{
17 “A Severa não morreu . . ., in Obras Literárias (Lisbon: Cosmos, 1973), 13:149-50.

${ }^{18}$ In this sense the parallel with Béla Bartók seems to be evident. See Judit Frigyesi, "Béla Bartók and the Concept of Nation and Volk in Modern Hungary," The Musical Quarterly 78, no. 2 (1994): 254-87.

19 "Estado actual da cultura musical em Portugal," in Obras Literárias, (Lisbon: Caminho, 1989), 6:91.

20 “A música portuguesa no século XIX," in Obras Literárias, (Lisbon: Caminho, 1989), 6:91ff.

21 “As óperas de Rui Coelho e o problema da ópera portuguesa," in Obras Literárias (Caminho), 6:166-67.

${ }^{22}$ Diário de Lisboa, February 8, 1924.
} 
"administered" folklore brought the fusion of art and politics as a nationalist state policy to its ultimate consequences, and included, notably, in its musical dimension, organized ranchos folclóricos ("folklore groups”) which disseminated Portuguese dances or danced songs by means of broadcasting, festivals, tourist events, tournées, and the like. Such folklore groups, together with fado, ${ }^{23}$ continued to inspire certain manifestations of "high art" such as, for instance, the repertoire of the ballet company "Verde Gaio" (created by the Secretary for Propaganda in the early 1940s). ${ }^{24}$

\section{Lopes-Graça's "politics of identity" and search for a "Portuguese music"}

A constellation of facts led Lopes-Graça, exiled in Paris since 1937, to reconsider his attitude concerning folk music: the publication of Rodney Gallop's book (1936), containing many unknown Portuguese folk songs and dances that this ethnologist had collected and transcribed from his field research; the meeting with Bartók in Paris and knowledge of his work; and the stimulus received from the Polish singer Lucie Dewinsky, whom he also met in Paris and who asked him to compose Lieder based on folk songs-a repertoire which particularly interested her but of which she said there were no good Portuguese examples. ${ }^{25}$

The first of four collections of twenty-four folk songs for voice and piano was written by LopesGraça between 1939 and 1942, and from this moment on he regularly composed using folk sources and also occasionally carried out field research, or cooperated, especially from the late 1950s, with the Corsican ethnologist Michel Giacometti in the research and publication of field recordings.

In a 1940 text he summed up his new attitude towards folklore as the basis for a "Portuguese music." Briefly, here are the main assumptions:

- the worst enemy of an "authentic musical nationalism," of an "authentic Portuguese music," is that "placard nationalism" or "advertising nationalism" (nationalismo de cartaz), that "famous Portuguese music," that "political-artistic confusionism," "which neither knew any technique of its own, nor internal discipline," "which was empty of content and null as a high form of art," while the concept of national music should be neither political nor ethnic, but "ethnicaesthetic";

- his attitude concerning folk music was not that of a folklorist but that of a composer: he was interested in its aesthetic side, its "psychological and morphological potentialities," its "potential, sometimes dramatic, sometimes pathetic, sometimes lyrical," its expressivity and musicality;

- by working on a folk song, one should respect its "identity," and this meant not adapting it, for instance, according to the norms of tonal harmony, but following the possibilities it offered, for instance, in its modal structure and other peculiarities-an attitude that was not at all "reactionary," but rather a chance for renewal and openness to the "conquests of the modern music grammar." 26

\footnotetext{
${ }^{23}$ Some supporters of the New State in the 1930s condemned fado. They even made use of the adjective "morbid," also found in the aforementioned articles by Lopes-Graça, to characterize it. In the 1930s fado was not admitted into the choral repertoire of the Mocidade Portuguesa (see Silva, "Usos e abusos"). However, from the 1940s onwards it was absorbed by the ideological propaganda of the regime.

${ }^{24}$ On the organization of folklore by the New State, see the following essays in Vozes do Povo: Vera Marques Alves, "O SNI e os ranchos folclóricos”; Pedro Félix, "O concurso 'A Aldeia Mais Portuguesa de Portugal' (1938)”; Jorge Freitas Branco,

"Uma cartilha portuguesa: entre militância cultural e doutrinação política”; Maria Luísa Roubaud, "O Verde Gaio: uma política do corpo no Estado Novo"; and Silva, "Usos e abusos."

${ }^{25}$ See Lopes-Graça, "Sobre o conceito," 6:50-51.

26 "Sobre a canção popular portuguesa e o seu tratamento erudito," in Obras Literárias, (Caminho), 6:138-41.
} 
In developing his idea of an "ethnic-aesthetic relationship," Lopes-Graça stated:

All true work of art puts both these terms-individual, collectivity-into the equation. The former represents the formative, active, variable element, which is the artist; the latter is the informative, passive and, to some extent, permanent element, which is the traditional ethniccultural complex. ${ }^{27}$

The art of every people was, thus, "the product of an individual experience rooted in a collective tradition," which, to be "valid," should be "dynamic, striving for new conquests, and condition of progress." 28 So, "popular dances and songs" were "excellent material for the constitution of an autonomous national music," but needed to be "transcended." Otherwise, the stage of a "superficial," "picturesque," "merely regional" art could not be overcome. Only "individual creative power" was able to give "force" and "universality" to popular sources. This aesthetic criterion had priority. ${ }^{29}$

Simultaneously, however, it was necessary to raise the issue of what is to be defined as "popular music": "What is most often labelled as 'Portuguese popular music' are just miserable and dull counterfeits of authentic folk music." 30 Folklore "counterfeiting" (contrafacção), according to Lopes-Graça's description, consisted of the "mass production" of music stereotypes for theatre reviews, films, broadcast starlets, organized "folk groups," fado-singers, and so on. That is to say, Lopes-Graça implicitly referred here to the commodification of music, a process in which the category "popular" or "national" was self-reproduced as a cliché. He searched for an alternative, an "authentic" folk music, such as was still alive, notably, in rural communities. Unknown musical treasures could be discovered there, as Gallop's field research had demonstrated:

[These songs] are not at all simple and naïve things, but beautiful melodies, amply drawn, of a perfect plastic balance, a broad "breathing", and full of a potential, sometimes dramatic, sometimes pathetic, sometimes simply lyrical, which makes them small wonders of expression and musicality. ${ }^{31}$

The very notion of "authentic" or "genuine" should, however, be called into question. All versions found in field research were necessarily "authentic"; one could not be more or less "authentic" than the other. Hence, for him as a composer, what made the difference was once again the aesthetic criterion. ${ }^{32}$

Habermas' theory of the "dissociation" (Entkoppelung) of the system from the life-world may help to give stronger contours to Lopes-Graça's criticism of folklore and his own path as a composer. By dealing with the systemic differentiation of complex societies, Habermas approaches the process by means of which, for instance, economic and administrative systems become autonomous and self-regulated, so that they lose any links to integration mechanisms, beliefs, and values, which give sense to life or to existential assumptions of a community and its members. The life-world is in this way downgraded (herabgesetzt) to only one system among others, and this means that it can no longer play any controlling role over the differentiated autonomous systems and their immanent logic. On the contrary, the life-world becomes more and more exposed to its "colonization" by the system. ${ }^{33}$

\footnotetext{
27 “Sobre o conceito," 42.

${ }^{28}$ Ibid., 41-42.

${ }^{29}$ Ibid., 46.

${ }^{30}$ Ibid., 48.

31 “Sobre a canção," 142.

32 Ibid., 139.

${ }^{33}$ Jürgen Habermas, Theorie des kommunikativen Handelns (Frankfurt a. M.: Suhrkamp, 1985), 2:229-93.
} 
Considered from the point of view of these categories, what Lopes-Graça calls "folklore counterfeiting" consists of music as commodity absorbed by the system of the "music industry" ruled by market laws as well as the administrative machine of the "New State' and its branches of cultural politics, media, and propaganda. "Authentic folklore" was, on the contrary, the expression of the integrity of a culture, where music was still profoundly linked to the life-world of a rural community as one of its essential components. And although it was not static, but dynamic_as Lopes-Graça emphasizes-its changes, continuous re-elaboration and transformation, were rooted in a truly lived social and individual experience: it was related to the social functions and the idiosyncrasy of a concrete community.

Thus, in his criticism of the hegemonic ideology concerning folklore, Lopes-Graça denounced the exploration of the picturesque and the propaganda of conformist values, the absence of the "human drama and condition" or of a "laughter and a joy in which the primitive animalism of the ancient Dionysius stews." "He rejected folkloristic "high art" like that of the "Verde Gaio" ballet company, describing it as producing "essentially an ornamental and decorative [art]," in which "the ornament had become an affectation of style" and the "decoration a mix of gaudy colours and a placard for tourist propaganda," without "any profoundness of thought or emotional vehemence." Against this "frivolous" art, in which what was at stake was only "the entertainment of the senses, dandy amusement, aristocratic divertissement—characteristics of a class which enjoys the pleasures of a life of pomp, charm and happiness," Lopes-Graça opposed Art (with a capital letter) itself, "which is not an ornament of high society, but a roaring expression of Life." 35

In this way, Lopes-Graça seems to have been aware of the mechanisms to which Georges Bataille called attention in his analysis of the "psychological structure of Fascism." In an essay published in 1933 in the journal Critique Sociale, Bataille developed a theory of the State and Power in Fascism that is founded precisely on the concept of Otherness. According to Bataille, Fascism starts from the assumption of a "heterogeneous being" (with regard to everyday life) which has in common with ancient forms of religious, military, and royal power its ideological emergence as tout autre, as the Other. ${ }^{36}$ Fascism would present itself in this sense as a "concentration" and "condensation of Power," or-also in his words-as a "condensation of superiority." ${ }^{\text {"B }}$ Bataille stressed, incidentally, the special link of Fascist power with the socalled "miserable classes," which was based on their identification with the "will of a small number or even of only one." A statement by Mussolini quoted by Raul Proença in one of his anti-fascist articles in the Portuguese journal Seara Nova-published on 6th March 1926, before the military putsch which would give rise to the "New State" in Portugal—clarifies this connection: "People have no need for education, they only need someone to guide them." Replying to a representative of Portuguese Fascist thinking, linked to Catholic "integralism," Proença specifies the meaning that such a link could have in Portugal: "If the Fascist handbooks preach Catholicism, it is as the morality of slaves, for the use of the populace. The morality of the leaders is another (a Nietzschian and anti-Christian one)."38 This means that the "radical heterogeneity" or Otherness of the Fascist elite had its counterpart in the idea of the common people as the inferior Other - an inferior Other that should as such be homogenized. In Portugal this homogenization included "folklore counterfeiting" with the aim of creating images of national identity in which common

\footnotetext{
34 “Sobre o ‘Cancioneiro Minhoto’ de Gonçalo de Sampaio,” in Obras Literárias (Lisbon: Caminho, 1989), 7:147

35 "Bailados do Verde-Gaio," Obras Literárias (Lisbon: Caminho, 1990), 8:267-68.

${ }^{36}$ Bataille, Georges. "La structure psycologique du fascisme," in Eeuvres Complètes, (Paris: Gallimard, 1970), 1:348 and $356 \mathrm{ff}$.

${ }^{37}$ Bataille, "La structure psycologique," 1:363.

${ }^{38}$ Seara Nova, March 13, 1926.
} 
people saw themselves as an inferior Other: they should feel that they needed to be guided. At the same time, however, "high art"-and this was particularly evident in the Portuguese concert and opera milieus-was strongly taken to be an art of the heterogeneous, ruling elite, which frequented an Opera House (Teatro de São Carlos, Lisbon) in which, until the mid-1950s, only people in evening dress were admitted to concert, opera, and ballet performances as a function of the "aestheticization of politics." 39

Thus, in referring to the so-called 'Popular Concerts' promoted in the 1940s by the group "Renascimento Musical" and performed in Coliseu, the biggest playhouse in Lisbon, Lopes-Graça expressed his opposition to the idea "of bringing culture to the common people" as a kind "of charity," which would consist of offering it "the remains," "the sub-products," "the trash," in this case "little lovely works and commonplaces to be whistled." "It was for the same reason that he protested against "folklore counterfeiting," in so far as it also reproduced "trash," "sub-products," and "commonplaces"—which means, again in Habermasian terms, that he protested against the colonization of the people's life-world by the system. "There is not a popular culture and an aristocratic culture, there is only culture," Lopes-Graça wrote, expressing in these words a conception of the integrity of culture in which both so-called "great music" and "authentic" folk music participated. Just as common people were able to understand and love what the elite took for "great music," so should intellectuals get to know "authentic" folk music: music that, as an emanation of the people's life-world, was still able to resist the system. ${ }^{41}$ Here, in my view, resides the core of Lopes-Graça's own project from the late 1930s.

\section{Transgression and counter-hegemony}

Lopes-Graça would carry out his project not only by composing and by intervening very actively in the public sphere as an opinion maker, through his intense activity as a music critic, essayist (18 books), editor (of a music periodical and a dictionary of music), and translator, ${ }^{42}$ but also by creating what could be called alternative socio-communicative structures. He founded, notably, the concert society Sonata for the performance of contemporary music, and the Choir of the Academia de Amadores de Música, composed of women and men from very different social origins and professions, who had in common, not a specific musical ability, but engagement in cultural and political resistance. The former became a meeting point for intellectuals, artists, students, and activists of the labor movement. For forty years, the latter brought Lopes-Graça's vision and experience of Portuguese folk music both to the intellectual and to the industrial and rural labor milieus in the form of about two hundred arrangements of folk songs specifically written for the choir. ${ }^{43}$

\footnotetext{
${ }^{39}$ This rule of etiquette lasted for evening performances until 1970 and for premieres until 1974, and was only fully abolished after the April Revolution (1974). For a more extensive discussion, see Vieira de Carvalho, 'Pensar é morrer,'218-28; or 'Denken ist Sterben,'277-89.

${ }^{40}$ Lopes-Graça, "Cultura ou demagogia musical?," in Obras Literárias (Lisbon: Cosmos, 1973).

41 "Valor estético, pedagógico e patriótico da canção popular portuguesa,” in Obras Literárias (Lisbon: Caminho, 1989), 7:103ff.

${ }^{42}$ In 1950 Lopes-Graça founded and edited the music periodical Gazeta Musical (later Gazeta Musical e de Todas as Artes). After having been forbidden by the Minister of Education in 1955 from becoming a private school teacher because of his political activism (he had been prevented from teaching in the public sector since 1931), he worked on the sketches for a Dictionary of Music left by his teacher Tomás Borba and translated, among other works, Romain Rolland's Beethoven (1963). See Lopes-Graça and Tomás Borba, Dicionário de Música (Ilustrado), 2 vols. (Lisbon: Cosmos, 1956-58).

${ }^{43}$ See Vieira de Carvalho, Fernando Lopes-Graça: Pensar a Música, Mudar o Mundo (Porto: Campo das Letras, 2006), in which some of the main ideas of the present paper are already suggested.
} 
Such multifaceted activity was rooted in a broader democratic and anti-fascist resistance movement, contributing to the development of the latter as a "counter-hegemonic position" in the Gramscian sense. ${ }^{44}$ Although Lopes-Graça never refers to Gramsci and, contrary to Gramsci, postulates a mediated relationship between art and ideology, it seems obvious that his whole intervention as an artist and an intellectual had the objective aim of giving rise to a "new culture," from which a "new art" could result. ${ }^{45}$ In the case of Lopes-Graça, the "new" at stake was the construction of an alternative "Portuguese identity."

Starting from what he called "the musical, psychological and sociological analysis" of folk songs and dances, he attempted to incorporate the characteristics related to the life-world of a given community and its "difference" into his arrangements. ${ }^{46}$ Thus, in opposition to a homogeneous image of Portuguese folk music, he postulated and attempted to show its diversity; and in opposition to the dominant stereotype of the Portuguese people as being both happy and resigned, he brought to the fore the potential for resistance, self-affirmation, and transgression. Even the musical testimonies of folk religiosity did not cease of fascinating him, an avowed atheist, for their ardent authenticity in situations of mourning and sorrow (as in the Commendations of the souls), pagan irreverence and superstition, also moments of non-conformism or social protest, contrasting with the canons of 'official' Catholicism.

In addition, by dealing with musical folk material, both in arrangements of complete songs for choir or for voice and piano, and in freer re-elaborations for piano or for different kinds of instrumental groups (including the orchestra), Lopes-Graça adopted a "critical method" (in his words) ${ }^{47}$ that rendered as problematic the approach to popular sources. It raised a kind of balance between identification and distance, so that the effect on the side of reception was also that of stimulating a critical attitude. Therefore, instead of having the effect of homogenizing the public, his music (not only that based on folk sources) divided it—as one could say, invoking Walter Benjamin interpretation of Brecht. ${ }^{48}$ In its substance, and in many technical and expressive senses, it gave voice to a people as a transgressive and counter-hegemonic Other. This seems to be evident in the following dimensions:

- dissonance as anti-climax in his works means not only the assimilation of Debussy's heritage by a composer of art music, but also the making explicit of a potential harmonic Otherness (the tonal norm-even in folk songs which are originally tonal-instead of being accepted as such, is challenged);

- dissonance can also be understood here as the projection of differences of intonation between folk performers singing polyphonic traditional songs (that which should be "corrected" according to an academic norm, is taken into the arrangement to make sense as transgression);

- rhythmic discrepancies are "composed" as if the different choral parts were not "in phase";

- other rhythmic and metric irregularities are also not normalized, but even intensified;

- what seem to be "mistakes" in prosody, including the frequent break of a syllable to introduce a breath (which should also be corrected according to the norm of vocal art music) are

\footnotetext{
44 'Hegemony' and 'counter-hegemony' are Gramscian categories. For an introduction to Gramsci's theory, see Renate Holub, Antonio Gramsci: Beyond Marxism and Postmodernism (London: Routledge, 1992), 3-30.

${ }^{45}$ Antonio Gramsci, "Arte e cultura," in Quaderni del Carcere, ed. Valentino Gerratana (Turin: Einaudi, 1977), 2192-3. In Lopes-Graça's theory and praxis as a composer there is a tension between musical autonomy and political engagement that cannot be discussed here. In some aspects he comes rather closer to Theodor W. Adorno's criticism.

${ }^{46}$ See Lopes-Graça, “Apontamento sobre a canção alentejana” (1946), Obras Literárias, 8: 175-183.

${ }^{47}$ See Lopes-Graça, "Criação e crítica na música portuguesa” (1943), Obras Literárias 6:31, footnote.

${ }^{48}$ Walter Benjamin, "Was ist das epische Theater? (1)," in Gesammelte Schriften, ed. Rolf Tiedemann and Hermann Schweppenhäuser (Frankfurt a. M.: Suhrkamp, 1991), 528. The convergence with Gramsci's "meaning-producing reader" in the case of music, "listener" - could also be added.
} 
transformed into moments of dramatic expression that recall the ancient forms of hoquetus or of largo e stacatto as rhetorical figures of crying or sobbing, notably in the choral arrangements of Encomendações das almas ("Commendations of the Souls").

Finally, in so far as Lopes-Graça sought to recover the folk experience of the life-world in its expressive nuances and intensity, he frequently stressed in his music the transgressive behavior that he found in such experience. Joy as transgression is especially perceptible in the third of the Three Portuguese Dances for Orchestra (1941), particularly in its final bars, in which a technique learned from Ravel is put in service of the Portuguese traditional dance Malhão. At the end of the piece, the depiction culminates in the auditory image of loud laughter (by the trumpets), a kind of popular joy that seems to become increasingly threatening.

In conventional concert halls, Lopes-Graça's folk-based music was the counter-hegemonic Other that symbolically burst into the room. The alternative structures of communication developed by his Sonata Society and his Choir of the Academia de Amadores de Música addressed rather non-conventional audiences, breaking social boundaries of music culture, its established circles. Finally, there was also his repertoire of "heroic songs"-music for political action-composed since the 1940s, which were no longer to be listened to as presentational music, but rather to be freely appropriated by common people as colloquial music in political demonstrations and other political events, at home or even in prisons, where oppositionist militants were incarcerated. ${ }^{49}$

These different dimensions of Lopes-Graça's musical activity raise questions that should be more extensively discussed but go beyond the purpose of this paper. They include notably, questions having to do with the complex and, in the proper sense, dialectical relationship of aesthetic autonomy and political engagement that characterizes Lopes-Graça's artistic profile. Be that as may, it could be said that LopesGraça developed a strategy of cultural resistance in which the politics of identity both assumed crucial relevance and required aesthetic mediation:

... by claiming, for Portuguese music, a closer contact with the people, I don't mean to immolate it, as art, to any ideological doctrine, in a sacrifice or commitment which would profit neither art nor ideology... "Portuguese music" must be defined according to an essentially aesthetic criterion. ${ }^{50}$

By developing such a strategy in theoretical thought, musical composition, and socio-communicative structures, Lopes-Graça "positioned" himself, his own music, and his whole artistic work as representatives of a counter-hegemonic "Portuguese identity."

\footnotetext{
${ }^{49}$ See Vieira de Carvalho, "Lebendige Aktion gegen geträumte Aktion: Musik und antifaschistischer Widerstand in Portugal," in Musik/Revolution. Georg Knepler zum 90. Geburtstag, ed. Hanns Werner Heister (Hamburg: von Bockel, 1997). A more detailed analysis of this repertoire would be the subject of a separate paper.

${ }^{50}$ Lopes-Graça, "Sobre o conceito," 60-61.
} 


\section{References}

Alves, Vera Marques. "O SNI e os ranchos folclóricos.” In Vozes do Povo - A Folclorização em Portugal, edited by Salwa Castelo-Branco and Jorge Freitas Branco, 191-205. Oeiras: Celta Editora, 2003.

Bataille, Georges. "La structure psycologique du fascisme." In Euvres Complètes, 1:339-71. Paris: Gallimard, 1970.

Benjamin, Walter. "Was ist das epische Theater? (1)." In Gesammelte Schriften, edited by Rolf Tiedemann and Hermann Schweppenhäuser. 2:519-31. Frankfurt a. M.: Suhrkamp, 1991.

Colaço, Alexandre Rey. De Música. Lisbon: Imprensa Libanio da Silva, 1923.

Félix, Pedro. "O concurso 'A Aldeia Mais Portuguesa de Portugal' (1938)." In Vozes do Povo - A Folclorização em Portugal, edited by Salwa Castelo-Branco and Jorge Freitas Branco), 207-32. Oeiras: Celta Editora, 2003.

Ferreira de Castro, Paulo. "Musical Nationalism, or the Ambiguities of Portugueseness." In Portugal and the World - The Encounter of Cultures in Music, edited by Salwa El Shawan Castelo-Branco, 163-70. Lisbon: Publicações Dom Quixote, 1997.

Freitas Branco, Jorge. "Uma cartilha portuguesa: entre militância cultural e doutrinação política.” In Vozes do Povo - A Folclorização em Portugal, edited by Salwa Castelo-Branco and Jorge Freitas Branco), 23343. Oeiras: Celta Editora, 2003.

Frigyesi, Judit. "Béla Bartók and the Concept of Nation and Volk in Modern Hungary." The Musical Quarterly 78, no. 2 (1994): 254-87.

Gallop, Rodney. Portugal: A Book of Folk-ways. Cambridge: The University Press, 1936.

Gramsci, Antonio. “Arte e cultura.” In Quaderni del Carcere, edited by Valentino Gerratana, 3:2192-93. Turin: Einaudi, 1977.

Habermas, Jürgen. Theorie des kommunikativen Handelns. 2 vols. Frankfurt a. M.: Suhrkamp, 1985.

Hall, Stuart. "Cultural Identity and Diaspora," In Identity: Community, Culture and Difference, edited by Jonathan Rutherford, 222-37. London: Lawrence \& Wishart, 1990.

Holub, Renate. Antonio Gramsci: Beyond Marxism and Postmodernism. London: Routledge, 1992.

Leça, Armando. Da Música Portuguesa. Lisbon: Lúmen, Empreza Internacional Editora, 1922.

Lopes-Graça, Fernando. "A música portuguesa no século XIX." In Obras Literárias. Vol. 6, A Música Portuguesa e os seus Problemas I, 63-84. Lisbon: Caminho, 1989.

- “A Severa não morreu ....” In Obras Literárias. Vol. 13, Disto e Daquilo, 149-55. Lisbon: Cosmos, 1973.

- "Apontamento sobre a canção alentejana." In Obras Literárias. Vol. 8, A Música Portuguesa e os seus Problemas III, 175-83. Lisbon: Cosmos, 1973.

- "As óperas de Rui Coelho e o problema da ópera portuguesa." In Obras Literárias. Vol. 6, A Música Portuguesa e os seus Problemas I, 161-71. Lisbon: Caminho, 1989.

—_. "Bailados do Verde-Gaio." In Obras Literárias. Vol. 8, Talia, Euterpe E Terpsicore, 263-68. Lisbon: Caminho, 1990.

. "Criação e crítica na música portuguesa." In Obras Literárias. Vol. 6. A Música Portuguesa e os seus Problemas I, 15-33. 
- "Cultura ou demagogia musical?” In Obras Literárias. Vol. 8, A Música Portuguesa e os seus Problemas III, 167-71. Lisbon: Cosmos, 1973.

. "Estado actual da cultura musical em Portugal." In Obras Literárias. Vol. 6, A Música Portuguesa e os seus Problemas I, 85-102. Lisbon: Caminho, 1989.

. "Sobre a canção popular portuguesa e o seu tratamento erudito." In Obras Literárias. Vol. 6, A Música Portuguesa e os seus Problemas I, 137-44. Lisbon: Caminho, 1989.

—. "Sobre o 'Cancioneiro Minhoto' de Gonçalo de Sampaio." In Obras Literárias. Vol. 7, A Música Portuguesa e os seus Problemas II, 139-47. Lisbon: Caminho, 1989.

—. "Sobre o conceito de música portuguesa." In Obras Literárias. Vol. 6, A Música Portuguesa e os seus Problemas I, 35-62. Lisbon: Caminho, 1989.

. "Valor estético, pedagógico e patriótico da canção popular portuguesa." In Obras Literárias. Vol. 7, A Música Portuguesa e os seus Problemas II, 101-15. Lisbon: Caminho, 1989.

Lopes-Graça, Fernando, and Tomás Borba. Dicionário de Música (Ilustrado). 2 vols. Lisbon: Cosmos, 195658.

Rolland, Romain. Beethoven - Os Grandes Períodos Criadores. Translated by Fernando Lopes-Graça. 3 vols. Lisbon: Cosmos, 1963.

Roubaud, Maria Luísa. "O Verde Gaio: uma política do corpo no Estado Novo." In Vozes do Povo - A Folclorização em Portugal, edited by Salwa Castelo-Branco and Jorge Freitas Branco, 337-53. Oeiras: Celta Editora, 2003.

Silva, Manuel Deniz. "Usos e abusos do folclore musical pela Mocidade Portuguesa." In Vozes do Povo - $A$ Folclorização em Portugal, edited by Salwa Castelo-Branco and Jorge Freitas Branco, 255-63. Oeiras: Celta Editora, 2003.

Vieira de Carvalho, Mário. 'Denken ist Sterben.' Sozialgeschichte des Opernhauses Lissabon. Kassel: Bärenreiter, 1999.

- Fernando Lopes-Graça: Pensar a Música, Mudar o Mundo. Porto: Campo das Letras, 2006.

. "Lebendige Aktion gegen geträumte Aktion: Musik und antifaschistischer Widerstand in Portugal." In Musik/Revolution. Georg Knepler zum 90. Geburtstag, edited by Hanns Werner Heister, 2:325-47. Hamburg: von Bockel, 1997.

- 'Pensar é morrer', ou O Teatro de São Carlos na mudança de sistemas sociocomunicativos. Lisbon: Imprensa Nacional - Casa da Moeda, 1993. 